\title{
Neoliberal trends in collective bargaining and employment regulation in Spain, Italy and the UK: From institutional forms to institutional outcomes
}

\author{
Martí López Andreu \\ University of Leicester, UK
}

\author{
Corresponding author \\ Martí López Andreu, School of Business, University of Leicester, University Road, Leicester LE1 7RH, \\ UK \\ Email: mla21@leicester.ac.uk
}

\begin{abstract}
This article discusses the effect of neoliberal trends in employment regulation during the 2008 recession. Liberalization in employment institutions is a long-term trend reinforced by the implementation of austerity policies. I use EU-SILC panel data to discuss these trends in Spain, Italy and the UK in three periods: before the crisis (2004--07), during the crisis (2007-10) and under austerity (2010--13). Although liberalization reforms interacted with the existing institutional architectures, I find a common trend towards greater employer discretion. Crucially, this trend in institutional outcomes appears in countries with different formal institutional characteristics in employment and collective bargaining.
\end{abstract}

Keywords: liberalization, dualization, collective bargaining, employment models, austerity, Spain, Italy, UK

\section{Introduction}

How does neoliberalism affect employment institutions? The 'Varieties of Capitalism' (VoC) approach tends to assume the resilience of national employment institutions (Hall and Gingerich, 2009; Iversen, 2007). Conversely, Thelen (2014) highlights that incremental institutional change can result in radical transformation. Many authors insist that there is no common trend in the transformation of national employment models, highlighting the importance of national actors and institutions in dealing with liberalization challenges. Conversely, others have identified a common trend towards liberalization (Baccaro and Howell, 2017; Streeck, 2011). Such authors argue that neoliberalism is develops through existing institutional characteristics and power imbalances in each country.

To address these debates, I discuss the effect of the 2008 recession and the implementation of austerity policies with a neoliberal slant in three different countries: Spain, Italy and the UK. While in the first phase the responses to the crisis involved more or less successful classical Keynesian policies to boost demand, in the second phase the crisis was ideologically reframed as a product of state intervention and regulation (Heyes et al., 2012), leading in Italy and Spain to austerity policies targeting employment regulation and collective bargaining in order to increase contractual flexibility and to develop a greater 'marketization' of collective wage-settings (Marginson and Welz, 2015). These regulatory changes were aimed to strengthen employers' discretion in the labour market and to promote unilateral flexibility adjustments (Schulten and Müller, 2015), as already occurred in the UK --- a contrasting case that illustrates how different employment models interacted with the liberalization pressures.

I focus on how neoliberal 'reforms' affected employment insecurity, thus moving the analysis from changes in institutional forms to institutional outcomes. More specifically, I examine the effect of the recession and austerity policies on employees' transitions and on pay, using EU-SILC (statistics on income and living conditions) panel data to investigate three periods: pre-recession (2004--07), recession (2007--10) and austerity (2010--13). First, I investigate employees' transitions and pay 
changes in the same job in each period in each country. Second, I conduct a logistical regression to identify the socio-demographic and employment characteristics related to the transition to unemployment and the risk of pay decreases. These risks are discussed in the three periods analysed.

I first present the main approaches regarding neoliberal trends in employment regulation.

Second, I discuss the liberalization pressures affecting employment regulation and collective bargaining in each country. Then I describe the methodology used and present the results in two parts. First, I analyse the main dynamics in transitions of employees in each country; second, I discuss the factors related to the change to unemployment and pay reductions for each period. In the conclusions I argue that a common liberalization trend can be found, reflected in increased employment insecurity.

\section{Employment regulation and collective bargaining under liberalization pressures}

Liberalization is a long-term trend affecting employment institutions, but displaying two distinct paths in collective bargaining decentralization (Marginson and Sisson, 2004). Organized decentralization enables unions to maintain a strong regulatory role, and firm-level negotiation is regulated by multiemployer agreements; in countries with disorganized decentralization, multi-employer agreements do not provide a framework for lower levels. The interpretation of these trends is controversial. Authors in the $\mathrm{VoC}$ tradition recognise a common trend towards liberalization but argue that the concept includes very different realities and 'obscures more than illuminates' (Hall and Thelen, 2009: 22). Thelen (2014) has subsequently argued that institutions survive not by reproducing the stability of their models but through reconfiguration on the basis of significantly new political support coalitions. She identifies three main 'varieties of liberalization': deregulation, mostly affecting liberal models; dualization, characteristic of continental countries, where coordinating institutions are maintained but only a core of actors and workers remain covered; and embedded flexibilization, with more flexibility in coordination while retaining a high degree of coverage of protective institutions. The latter can be identified mainly in Scandinavian countries.

A second group of authors has identified a general trend towards liberalization affecting different institutional models (Baccaro and Howell, 2011, 2017; Streeck, 2011). They interpret liberalization in industrial relations as a part of a wider neoliberal project directly linked to the aim of capital to restore profitability. They argue that a common trend can be identified in the reinforcement of employer discretion in three dimensions: wage determination, work organization and discretion in hiring and firing (Baccaro and Howell, 2017: 19-20). Two movements are identified: first, institutional transformation through decentralization, individualization and the disorganization of collective capacities of organized labour; second, a shift in the role played by formally unchanged institutions from discretion-limiting to discretion-enhancing. This idea of 'institutional conversion' (Thelen, 2009) implies that institutional arrangements such as centralized collective agreements and social dialogue can be mechanisms to achieve neoliberal outcomes and not only to improve working conditions. Furthermore, this approach emphasizes the leading role of the state in strengthening liberalization pressures (Howell, 2016).

This discussion links to the employment regime approach (Gallie, 2013). This approach identifies southern European countries as following a partial and targeted deregulation affecting young workers ('deregulation at the margins') with conditions deregulated for new entrants (EspingAndersen and Regini, 2000). By contrast, 'continental' countries implemented a partial reform that divided the workforce between skilled-protected and unskilled-deregulated workers (Gash and Inanc, 2013) while Nordic countries followed a 'flexicurity' strategy combining high flexibility with high levels of social protection. Liberal regimes, such as the UK, further deregulated already weak systems of employment protection.

The 2008 crisis accentuated these differences. Comparative analysis has shown that, in the first phase of the crisis, sectoral and national agreements procedures in countries with well coordinated multi-employer bargaining systems provided certainties at firm-level (Crouch, 2014), and short-time work schemes supported by public policy facilitated coordinated responses. Conversely, in countries with single-employer agreements and low coverage of collective bargaining, unilateral 
employer responses dominated. This was also the case in countries with weak vertical coordination between multi-employer and single-employer agreements, as in southern European countries (Glassner et al., 2011, Lallement, 2011). The 'austerity turn' of 2010 led to further marketization of employment relations in these countries (Visser, 2015) and 'reforms' have tended to be unilaterally imposed by the state, acting in agreement with the EU institutions (Koukiadaki et al., 2016; Meardi, 2014)

In this context, Prosser (2015) has summarized two main approaches to deregulatory changes in Europe in the context of the 2008 recession: the liberalization approach, facilitating precarious and insecure employment for all workers; and the dualization approach, primarily affecting peripheral workers.

\section{Varieties of models and austerity reforms in Spain, Italy and the UK}

Spain and Italy possess dualist labour markets, segmented by type of contract, and centralized systems of collective bargaining (Amable, 2003, Molina and Rhodes, 2007). Although they have comparative high levels of collective bargaining coverage and elaborate frameworks of institutional union representation, the practical impact of joint regulation on employment conditions is weak (GumbrellMcCormick and Hyman, 2013). Although both are traditionally grouped together as 'Mediterranean' countries, significant differences exist (Jackson and Deeg, 2008). In the Spanish case the state has played a crucial role in the institutionalization of industrial relations to ensure and strengthen coordination, and employment regulation shows a high degree of juridification. Conversely, in Italy, voluntarism prevails and the institutional architecture of collective bargaining is the result of peaklevel agreements (Leonardi, 2017). Furthermore, although unions in both countries have relatively low associational power, the capacities of Italian unions are stronger, with a long tradition of microcorporatism. Union presence at workplace level in Spain is weaker and union strategies have focused to strengthen their institutional role (Köhler and Calleja, 2017). This has made Spanish unions especially weak in enforcing the contents of multi-employer agreements and sometimes even labour law at workplace level (Martínez Lucio, 1999).

Although both countries have centralized systems of collective bargaining, changes since the 1990s have reinforced decentralization. In Italy, state-sponsored reforms in 1993 and 1996 regulated negotiating levels and established a model described as 'controlled decentralization', increasing the importance of company bargaining but within the regulatory framework set by the national sector agreement (Bordogna, 1997). In Spain, a crucial legislative change in 1994 encouraged a disorganized decentralization of bargaining, with greater space for companies to opt out of clauses negotiated in higher-level agreements (Molina, 2014). The system moved towards organized decentralization in 1997 when government-sponsored bilateral dialogue established the priority of multi-level agreements. However, since then, Spanish unions have been strongly oriented to wage moderation (Molina, 2005).

The UK is the main representative of a liberal model in Europe. Characterized as a marketbased economy by Amable (2003), its employment protection is low and external flexibility shapes labour market dynamics as employers can hire and fire with ease. Furthermore, a long-term voluntarist tradition (Hyman, 2001) and policies to reduce union capacities since the 1980s (Waddington, 2000) have led to a decentralized system of single-employer collective bargaining with low coverage of collective agreements. Howell (2005) has identified the pivotal role of the state in deconstructing British collective employment relations and developing a minimalist system based on employer unilateralism. This decollectivization of employment relations included the narrowing of the conditions under which industrial action was protected with immunity, an intrusive regulation of trade union governance, the removal of state support for trade union activity and collective bargaining and labour market deregulation. The 'New Labour' governments from 1997 did not substantially change the trend towards decollectivization and emphasized the creation of individual rights at work, enforceable through labour courts and state agencies (Baccaro and Howell, 2017).

The 2008 recession strongly affected all three countries but in different ways. According to the Eurostat Labour Force Survey, unemployment increased from 8.2 percent in 2007 to 19.9 percent 
in 2010 in Spain, but less drastically in Italy (from 6.1 percent to 8.4 percent) and the UK (from 5.3 to 7.8 percent). Unemployment rates continued to increase in Spain (to 26.1 percent in 2013) and Italy (12.1 percent), while in the UK the rate started to fall after 2011. However, all three countries have been affected by regulatory changes that have strengthened liberalization pressures. Spain suffered the most drastic changes in a series of legislative 'reforms' opposed by organized labour. These included a deregulation of collective bargaining, leading towards disorganized decentralization (Marginson et al., 2014) and reinforcing the capacities of employers to introduce 'internal flexibility' in working time and task definitions without the need to negotiate (Banyuls and Recio, 2015). Moreover, a time limit was imposed on the 'after-effect' of expired agreements and the previously existing short-time working scheme can now be applied unilaterally by the employer. The capacity of employers to hire and fire has been facilitated by the reduction of dismissal costs and by the broadening of causes for objective dismissal. This reflects the traditional demands of the most neoliberal faction of employers' organizations (Fernández Rodríguez and Martínez Lucio, 2013). Public sector workers were also affected by downgrading of their working conditions, including a freeze on wages and a virtual freeze on new hiring (Muñoz de Bustillo and Antón, 2013). After a lack of peak level agreements since the crisis in 2012, one was signed by the main unions and employer organizations to establish very low maximum pay increases ( 0.5 percent in 2012 and 0.6 percent in 2013) and, more importantly, to establish economic indicators instead of inflation to index maximum pay increases in 2014 (between 0.6 percent and 1.5 percent).

Despite important changes, the Italian model remained less affected in its core characteristics and remains a coordinated and organized one (Leonardi, 2014: 78). New legislation allowed company agreements to diverge not only from sectoral agreements but also from dismissals and employment law (Rocha, 2014). However, peak agreements reached by main unions and employers' organizations in 2011 and successive years re-established the primacy of the sectoral level, though it is now possible to adopt 'modifying agreements' at company level if this is permitted by the sectoral agreement. Moreover, the role of social actors has been maintained in the reinforcement and inclusion of more sectors in the short-time working scheme that previously existed in manufacturing. However, protection for workers in standard employment has been reduced while some restrictions have been applied to the use of temporary contracts. Furthermore, public sector workers were also affected by a wage freeze and a virtual freeze on new hiring. These trends lead Picot and Tassinari (2017: 465) to characterize liberalization pressures in Italy as 'embedding flexibilization', consisting of a flexibilization of coordination while improving coverage but from low levels, whereas they identify a clear deregulatory trend in Spain.

In the UK the neoliberal approach towards employment rights has been strengthened. The 'two-tier code', a measure that ensured that public sector agreements were in practice extended to workers in private sector organizations subcontracting services to the public sector, has been abolished (Grimshaw and Rubery, 2012). In the context of budget restrictions this has reinforced the pressures towards worsening working conditions in outsourced activities. Employer discretion to hire and fire has increased by extending the period before unfair dismissal can be claimed, and the minimum consultation period for large-scale collective redundancies has been reduced. The statutory right to flexible working for parents has been replaced by a voluntary 'code of practice' and workers in the public sector have been affected by a wage freeze and substantial job losses (Grimshaw, 2012).

In summary, the three countries have different starting points and have been affected differently by liberalization pressures. The UK has reinforced its already neoliberal approach. Spain, and to a lesser extent Italy, has been affected by attempts to liberalize employment regulation and collective bargaining. Below I analyse how the three models interacted with these dynamics.

\section{Methods}

To analyse how the employment models of the three countries have been affected by the 2008 recession and austerity measures I use the EU-SILC panel data provided by Eurostat, which permit an analysis of changes in employment and annual income of individuals. EU-SILC provides longitudinal data for 31 European countries (Iacovou et al., 2012) over a maximum of four years, permitting an 
analysis of three periods: pre-recession (2004--07, except in the UK where EU-SILC did not start until 2005), recession (2007--10) and austerity (2010--13). However, because its rotation sample, there is an erosion of the number of cases with information available for the four years. These limitations mean that $\mid \mathrm{I}$ focus on changes between two consecutive years. The panel data do not include variables that enable us to differentiate between public or private sector or economic activities. Despite these limitations, this dataset is unique in offering the possibility to identify changes over time in employees' working conditions.

The use of these three periods has enabled an analysis of the main changes in the employment models of the three countries analysed. Two main dimensions are considered. First, changes in employment status between $t-1$ and $t$ in terms of job change and transitions to unemployment and other non-employment situations (education and training, domestic care and other inactivity). Second, for those employees in the same job at $t-1$ and $t$, changes in annual pay, presented in three categories: real pay increase, nominal increase or no change, and pay decrease. The average of these dimensions in each period permits us to characterize the models and their trends of change. More concretely, they allow us to identify whether changes are mainly achieved by external flexibility (job change or transitions to non-employment), internal flexibility (pay decrease in the same job) or both types of flexibility.

Second, a logistical regression is used to identify the socio-demographic and employment factors related to the transition to unemployment and pay decrease. The independent variables include sex, age (squared), occupation and other employment variables in $t-1$ such as working time and type of contract. The dependent variables of the two models are the change to unemployment (against keeping the job) and pay decrease (against a real pay increase). Moreover, in the model analysing pay decrease another variable is included, change in working hours, calculated as working hours in $t$ minus working hours in $t-1$ to control for lower pay caused by reduced working hours. To identify change provoked by the periods defined as recession and austerity the model includes an interaction of the independent variables with 'period'. This variable takes value 0 for 2004--07, 1 for 2007--10 and 2 for 2010--13. This permits us to identify the significant variables in the pre-recession period (baseline of the model) and then the change in each subsequent period against this baseline.

\section{Findings}

\section{Trends in employee transitions}

This section discusses the changes in employee transitions during recession and austerity. Table 1 shows the changes between year $t-1$ and year $t$ in the three periods. Before the crisis, in both Spain and the UK about 44 percent of all employees had a real pay increase over the previous year and under 30 percent a decrease. However, Spain showed a higher rate of transition to unemployment than the UK; conversely, fewer employees changed job (11 percent) than in the UK (almost 18 percent). Furthermore, external mobility in Britain was much more related to a real pay increase than in Spain. Similar figures can be identified in pay change of employees in the same job in two consecutive years. In Italy more than half of employees had a real pay increase and under a quarter a decrease. There was also a much lower transition to unemployment than in Spain and more than 60 percent of employees in the same job had a real pay increase in the period.

Table 1 about here

The main effect of the crisis (2007--10) in Spain was external adjustment. Transitions to unemployment grew by more than 4 points and job change decreased by -3.4 points, as job losses were concentrated in temporary employment (Muñoz de Bustillo and Antón, 2011). However, the structure of collective bargaining led to relative pay stability: pay increases were inflation-linked, and collective agreements remained valid for an unlimited 'after-effect' period when they expired. Italy was affected by less dramatic changes in external flexibility; indeed job changes slightly increased, with goring use of temporary contracts for new entrants in parallel with job losses concentrated in 
temporary jobs (Simonazzi, 2015). Transitions to unemployment increased only slightly, by 0.7 points. In this period, the number of employees in the same job with a pay decrease grew by more than 7 points. In the UK, adjustments combined changes both in pay and in the external labour market. In this flexible model, the economic crisis tended to cause more job mobility than unemployment (Rubery and Grimshaw, 2003). Accordingly, job change fell from 17.7 percent to 12.1 percent, while unemployment increased from 1.1 to 2.7 percent, a substantial increase but starting from low levels. At the same time, pay decreases grew by more than 7 points among employees in the same job. In both Italy and the UK, pay adjustments were surprisingly similar. However, we should acknowledge that this was achieved in different ways: multi-employer agreements and microcorporatist practices predominated in Italy but unilateral employer responses in the UK (Van Wanrooy et al., 2014).

Austerity policies in the second phase of the crisis brought a different story. In Spain, transitions to unemployment increased slightly, to a very high 10.5 percent, although the main external adjustment involved the further collapse of job changes. In contrast to the previous period, there a strong adjustment in pay: employees in the same job with a decrease grew by 9 points to 45.7 percent, and nominal pay increases or no change grew from 9.3 percent to 12.5 percent, resulting in a fall in more than 12 points in employees with a real pay increase. Previous research has shown that, despite these deep changes, during this period the high levels of collective bargaining coverage were maintained and multi-employer agreements prevailed (Malo, 2016). The trend towards lower pay was achieved by the increased use of 'opt-out' clauses by employers and by multi-employer agreements with low or negative pay increases (López-Andreu, 2018). In Italy, transitions to unemployment increased more than in the previous period (about 2 points against 0.7 ) and job changes fell by -4.7 points. In parallel, employees in the same job with a real pay increase fell by -7.6 points, with an increase of 2.4 points in pay decreases. In the UK, despite a slight economic and employment recovery, pay did not improve. Transitions to unemployment decreased by -0.8 and job changes by 1.3 points; but employees in the same job with lower pay went up by 1.2 and those with the same pay or a nominal pay increase by 1.5 points.

\section{Changing patterns in the transition to unemployment and pay decreases}

This section analyses the socio-demographic and employment factors related to transitions to unemployment and pay decreases. The first model identifies the risk of change to unemployment (against keeping the current job). Spain before the crisis fits a model of 'flexibility at the margins'. For example, being a woman, young and with a temporary contract increased the risk of unemployment. In its highly segmented labour market, high- and medium-skilled clerical workers and plant and machine operators had a lower probability than elementary occupations. The economic crisis modified some of these patterns. The sectors more affected by job losses (manufacturing and construction) employed mostly men and therefore the figures show a lower risk for women, both in recession and under austerity. The risk for clerical workers and skilled manual workers increased, the latter showing the high incidence of the crisis in the construction sector in Spain. Conversely, in the austerity period there was a significant growth in the risk of unemployment among professionals. This shows that the deregulatory changes of the period, including public sector cutbacks, spread the risk to core workers previously not affected. Furthermore, during this second period the differences in the risk of unemployment between types of contract was reinforced.

In the model that considers pay decreases among employees in the same job (against a real pay increase), the figures before the crisis reveal that the risk increased with age, and that managers and clerical workers were less likely to be affected than elementary occupations. On the other hand, part-time workers were more affected than full-time workers whilst temporary workers were less likely to receive lower pay. This is predictable as not many temporary workers keep their job across two years (and those who dot tend to be working in long-term projects). During the first phase of crisis the risk increased for managers, potentially related to cuts in overtime and bonuses, while professionals, associate professionals and clerical workers faced increased risk during the austerity period. This again suggests that austerity policies increased the risk of in-job insecurity for core 
segments of the labour market. This is also related to the higher risk for full-time workers. The risk of a pay decrease in this period was linked to working more hours, suggesting that working-time adjustments and short-time working time schemes did not play an important role in pay adjustments in the whole economy.

\section{Table 2 about here}

In Italy, before the crisis, managers, professionals and clerical occupations had a lower risk of transition to unemployment than elementary occupations. Young workers and those with part-time and temporary contracts experienced a higher risk, as would be expected in a system characterized by 'flexibility at the margins'. The main changes in the factors related to transitions to unemployment were in the austerity period, when there was a substantial increase in unemployment, as noted above: core workers previously protected (men, older workers, clerical workers and plant and machine operators) faced increased risk. The probability of pay decreases in the pre-crisis period was lower among women and professionals and associate professionals, but increased with age and was higher among part-time workers. The crisis strengthened the effect of age and led to a higher risk of pay decreases for professionals. This is also the case for associate professionals and plant and machine operators in the first phase of the crisis. This could be related, in the case of manufacturing, to the wider use of the short-time working scheme (Simonazzi, 2015). The effect of the crisis for plant and machine operators has been, first, lower pay (probably because of short-time working) and, second, high risk of job loss in 2010--13. In this austerity period the risk for full-time workers increased, reinforcing the conclusion that insecurities have spread to core workers.

In the British flexible model, the risk of transition to unemployment before the crisis was higher for young and temporary workers and in elementary occupations and for plant and machine operators. This confirms the importance of class and market position for employment insecurity in the UK (Warren, 2015). The crisis spread the risk to older workers in both periods and, in the first phase, when transitions to unemployment grew significantly, the risk increased for associate professionals and plant and machine operators. These occupational groups reflect the growth of unemployment in sectors such as finance and manufacturing (Grimshaw, 2011). Before the crisis, older and part-time workers were more likely to have a pay decrease while the risk was lower among professionals. The most relevant change in this pattern was in the austerity period when women, professionals and fulltime workers experienced increased risk. This suggests that cutbacks in the public sector especially affected professionals and women, overrepresented in the public sector (Rubery and Rafferty, 2013).

This section shows the spread of risks to core workers previously protected in Spain and Italy. In both countries, the risk of job loss and pay decreases spread during austerity to segments of the workforce that had not been affected before the crisis or during the first phase. To a lesser extent, there was also an increased risk of lower salaries for professionals and women in the UK, related to public sector cutbacks.

\section{Discussion and conclusions}

This study reveals that in all three countries, liberalization policies implemented during austerity interacted with the existing institutional models and the effects of the 2008 recession. Two of the countries, Spain and Italy, were characterized before the crisis by a relatively high degree of employment protection, a dual labour market and multi-employer systems of collective bargaining. The employment and collective bargaining systems of these two first countries were affected by strong liberalization pressures during austerity. However, as argued by Thelen (2014) and Picott and Tassinari (2017), these pressures interacted with national institutions and actors and the effects differed between the countries. In Spain a clear deregulatory approach was taken by the state under pressure from the Troika, by-passing social dialogue, resulting in a change toward deregulation that has given priority to single-employer agreements. Conversely, although similar policies were implemented in Italy, this occurred in a less comprehensive manner, while the social actors reestablished the dominance of multi-employer agreements. In spite of that, the system in Italy has 
moved towards organized decentralization, with greater employer ability to hire and fire. By contrast, the UK was already a flexible market-led model with low coverage of collective agreements and the dominance of single-employer agreements, if any. Although the British model suffered fewer changes than in the two other countries, the measures implemented extended the existing flexible arrangements of the private sector to the public sector. These different experiences suggest that liberalization pressures are developed through the existing diversity of institutional arrangements. This finding is compatible with recent developments in $\mathrm{VoC}$ analysis, but also the liberalization hypothesis that suggests that there is no convergence towards a single model but rather a common trajectory of reinforcement of employer discretion (Baccaro and Howell, 2017). Furthermore, it can be argued that liberalization trends develop against the specific collective institutions and practices in each national context.

This article offers new insight for current debates by moving analysis from the institutional form (the formal characteristics and features of employment and collective bargaining institutions) to the institutional function and outcomes in terms of pay and employment transitions, developing a nuanced analysis which significantly advances our understanding of the impact of neoliberal pressures on employment institutions. First, I show that the institutional form itself does not provide enough explanation of employment patterns in different countries, at least in those analysed. The findings suggest a disconnection between institutions of joint regulation and outcomes, revealing a more complex relationship than that provided by traditional institutional comparative analysis. Second, I demonstrate that shifts in regulation and coordination are not a recent phenomenon but responses to a long-term trajectory against organized labour that has affected the countries analysed with different intensity and pace. Crucially, this is apparent when we move our analysis from institutional forms to outcomes (or institutional function). Before the crisis the Spanish model appeared more flexible in relation to pay than was expected given its collective bargaining system (high coverage and multiemployer agreements). In this regard, the behaviour of the Spanish labour market in terms of pay and external flexibility resembled in practice the flexible British model. Hence my findings highlight the need to attend not only to institutional characteristics but also to the complexity of relationships happening inside the regulatory space (MacKenzie and Martínez Lucio, 2005) and the need to understand the different sources and balances of power of industrial actors (Baccaro and Howell, 2017).

This approach is reinforced when we discuss the impact of austerity 'reforms' on the dynamics of employment insecurity. The drastic changes in Spain led to a radical shift towards lower pay for employees in the same job, while in the first phase of the crisis external flexibility dominated. In parallel, unemployment insecurity remained high. However, this 'internal devaluation' (Hermann, 2014) was achieved in a system that maintained high levels of bargaining coverage and the predominance of multi-employer agreements. In the Spanish case, a sequential trajectory of, first, institutional drift (increased use of opt-out clauses by employers) that eroded union capacities, and, second, institutional conversion (multi-employer agreements with negative or low pay increases), led to lower pay while institutional characteristics were maintained (López-Andreu, 2018). These findings suggest, again, that the dynamics and processes inside the institutional space were crucial to explain employment outcomes.

Similarly, although Italy maintained most of its institutional characteristics during the austerity period, both types of flexibility intensified, revealing that changes in power imbalances between actors rather than formal institutional characteristics played a key role in explaining employment outcomes, corroborating previous findings of Baccaro and Howell (2017: 142). However, the Jobs Act 2014-2015 (outside our period of analysis) has further deregulated the labour market and its impact needs to be considered by future research.

Unilateralism predominated in the UK in the first phase of the crisis, and the austerity period revealed the persistence of both types of flexibility. The decollectivization of employment rights, the decline of collective bargaining and the promotion of individual rights led to unilateral employer responses, with or without consultation. Crucially, during the austerity period the main policy initiatives in the UK targeted union capacities and existing collective bargaining practices in the public sector. These data suggest that despite different starting points and path dependencies, the three countries moved to greater employer discretion resulting in higher employee insecurity. 
Furthermore, these elements can also be identified in the discussion of the variables related to transitions to unemployment and to lower pay. Before the crisis, employment insecurity in Spain and Italy followed the pattern of 'liberalization at the margins' and in the UK that of 'market power'. Although during the crisis some of these elements were modified given its particular impact in specific sectors in each country, the findings reveal that during austerity risk spread to groups of workers who had previously been less affected. This is clear in the Spanish and Italian cases but also in Britain as the risks spread to public sector workers. Considering the liberalization and dualization approaches proposed by Prosser (2015), my findings support the liberalization approach as risks have tended to spread to all workers in the three countries and have been less concentrated among specific groups.

Finally, these findings highlight the need to extend the debate regarding liberalization pressures from the form of institutional architectures to the outcomes on employment insecurity. Traditional research on comparative employment relations has tended to focus on the formal characteristics and features of employment institutions. More recently, analysis concerning the impacts on joint regulation of austerity policies has increasingly suggested a turning point. In this article I have discussed relationships between contexts, neoliberal reforms and outcomes in employment insecurity, highlighting a disconnection between institutional characteristics and outcomes, exemplified by employment insecurity. My analysis has shown that deregulation is a longterm trend in which current policy shifts are a further (but not new) step. In order to understand the processes happening inside each model, a different type of research is needed. This will require intensive case studies to understand the complex relationship between neoliberalism and institutions and to analyse how policy change interacts with the specific collective nature of institutions (and their trajectory of change) and the sources of power of industrial actors in each country. My findings also illustrate that traditional union sources of power (such as institutional power) are greatly weakened under neoliberalism and that innovative regulatory and organizing strategies may be necessary to strengthen union power, regulate and fight increasing inequalities.

\section{Funding}

The primary research for this article was supported by the European Commission (Marie Curie Intra European Fellowship 'Labour trajectories in UK and Spain. Analysis of capabilities in transitions using a mixed-methods approach', TRANSICAP, ref. FP7-328223), undertaken at Manchester Business School.

\section{References}

Amable, B. (2003) The Diversity of Modern Capitalism. Oxford: Oxford University Press.

Baccaro, L. and Howell, C. (2011): 'A Common Neoliberal Trajectory: The Transformation of Industrial Relations in Advanced Capitalism', Politics \& Society, 39(4): 521-563.

Baccaro, L. and Howell, C. (2017) Trajectories of Neoliberal Transformation. European Industrial Relations Since the 1970s. Cambridge: Cambridge University Press.

Banyuls, J. and Recio, A. (2015): 'A crisis inside the crisis: Spain under a conservative neoliberalism' in Lehndorff, S. (ed.): Divisive integration. The triumph of failed ideas in Europe - revisited, Brussels, ETUI, pp. 39-68.

Bordogna, L. (1997) 'Un Decennio di Contrattazione Aziendale nell'Industria', in Bellardi, L. and Bordogna, L. (eds) Relazioni Industriali e Contrattazione Aziendale. Rome: FrancoAngeli, pp. 61-108.

Crouch, C. (2014): 'Introduction: labour markets and social policy after the crisis', Transfer 20(1): 722.

Emmenegger, P (2014), The Power to Dismiss. Trade Unions and the Regulation of Job Security in Western Europe, Oxford: Oxford University Press. 
Esping-Andersen, G. and Regini, M. (2000) Why Deregulate Labour Markets? Oxford: Oxford University Press.

Fernández-Rodríguez, C.J. and Martínez Lucio, M (2013): 'Narratives, myths and prejudice in understandings employment systems: The case of rigidities dismissals and flexibility in Spain', Economic and Industrial Democracy 3 (2): 313-336.

Gallie, D. (2013) Economic Crisis, Quality of Work, and Social Integration. Oxford: Oxford University Press.

Gash, V. and Inanc, H. (2013) 'Job Insecurity and the Peripheral Workforce' in Gallie, D. (ed) Economic Crisis, Quality of Work, and Social Integration. Oxford: Oxford University Press, pp. 142-168.

Glassner, V., Keune, M. and Marginson. P. (2011): 'Collective bargaining in a time of crisis: Developments in the private sector in Europe', Transfer 17(3): 303-321.

Grimshaw, D. (2012) 'Austerity, Privatisation and levelling down: Public sector reforms in the United Kingdom' in Vaughan-Whitehead, D. (ed.) Public Sector Adjustments in Europe, Geneva: ILO, pp. 575-626.

Grimshaw, D. and Rubery, J. (2012): 'The end of the UK's liberal collectivist social model? The implications of the coalition government's policy during the austerity crisis', Cambridge Journal of Economics 36(1): 105-126.

Gumbrell-McCormick, R. and Hyman, R. (2013) Trade Unions in Western Europe. Hard Times, Hard Choices. Oxford: Oxford University Press

Hall, P., and Gingerich, W. (2009) 'Varieties of capitalism and institutional complementarities in the political economy' British Journal of Political Science 39(3): 449-482.

Hall, P. and Thelen, C. (2009) 'Institutional change in varieties of capitalism', Socio-Economic Review 7(1): 7-34.

Hermann, C. (2014): 'Structural Adjustment and neoliberal Convergence in labour Markets and Welfare: The Impact of the Crisis and Austerity measures on European Economic and Social Models', Competition and Change 18(2): 111-130.

Heyes, J., Lewis, P. and Clark, I. (2012): 'Varieties of capitalism, neoliberalism and the economic crisis of 2008 -?', Industrial Relations Journal 43(3): 222-241.

Howell, C. (2005) Trade Unions and the State: The construction of of Industrial Relations Institutions in Britain, 1890-2000. Princeton: Princeton University Press.

Howell, C. (2016) 'Regulating class in the neoliberal era: The role of the State in the restructuring of work and employment relations', Work, Employment and Society 30(4): 573-589.

Hyman, R. (2001) Understanding European Trade Unionism. Between Market, Class and Society. London: Sage.

Iversen, T. (2007): 'Economic shocks and varieties of government responses', in B. Hanké, M. Rhodes and M. Thatcher (eds) Beyond Varieties of Capitalism. Oxford: OUP, pp. 278-306.

Jackson, G. and Deeg, R. (2008): 'Comparing capitalism: understanding institutional diversity and its implications for international business', Journal of International Business Studies 39(4): 540561.

Köhler, H-D and Calleja, J. P. (2017) 'Spain: a peripheral economy and a vulnerable trade union movement' in Lehndorff, S., Dribbusch, H. and Schulten, T. (eds) European trade unions in a time of crises. Brussels: ETUI, pp. 61-82.

Koukiadaki, A., Távora, I. and Martínez Lucio, M. (2016): 'Continuity and change in joint regulation in Europe: Structural reforms and collective bargaining in manufacturing', European Journal of Industrial Relations 22(3): 189-203.

Lallement, M. (2011): 'Europe and the economic crisis: Forms of labour market adjustment and varieties of capitalism', Work, Employment and Society 25(4): 627-641.

López-Andreu, M. (2018): 'Employment Institutions under Liberalization Pressures: Analysing the Effects of Regulatory Change on Collective Bargaining in Spain', British Journal of Industrial Relations.,doi.org/10.1111/bjir.12418.

Leonardi, S. (2017): 'Trade unions and collective bargaining in Italy during the crisis' in Lehndorff, S., Dribbusch, H. and Schulten, T. (eds) European trade unions in a time of crises. Brussels: ETUI, pp. 83-108 
MacKenzie, R., and Martínez Lucio, M. (2005): 'The realities of regulatory change: Beyond the fetish of deregulation' Sociology 39(3), 499-517

Malo, M. A. (2016): 'Collective bargaining reforms in Southern Europe during the crisis: impact in the light of international standards' in Pulignano, V., Köhler, H.D. and Stewart, P. (eds): Employment relations in an era of change. Multilevel challenges and responses in Europe. $\equiv$ ssels|: ETUI, pp. 117-135.

Margins assault?’ European Journal of Industrial Relations 21(2): 97-114.

Marginson, P. and Sisson, K. (2004): European Inregration and Industrial Relations. Basingstoke: Palgrave Macmillan.

Marginson, P. and Welz, C. (2015): 'European wage-setting mechanisms under pressure: Negotiated and unilateral change and the EU's economic governance regime', Transfer 21(4): 429-450.

Marginson, P., Keune, M. and Bohle, D. (2014): 'Negotiating the effects of uncertainty? The governance capacity of collective bargaining under pressure', Transfer 20(1): 37-51.

Martínez Lucio, M. (1999) 'Spain: Regulating Employment and Social Fragmentation', in A. Ferner and R. Hyman (eds) Changing Industrial Relations in Europe. Oxford: Blackwell, pp. 426458.

Meardi, G. (2014) 'Employment relations under external pressure: Italian and Spanish reforms in 2010-12' in Hauptmeier M. and Vidal M (eds) Comparative Political Economy of Work. Basingstoke: Palgrave Macmillan, pp. 332-350

Molina, O. (2005) 'Political Exchange and Bargaining Reform in Italy and Spain', European Journal of Industrial Relations 11(1): 7-26.

Molina, O. (2014) 'Self-regulation and the state in industrial relations in Southern Europe: Back to the future?', European Journal of Industrial Relations 20(1): 21-36.

Molina, O. and Rhodes, M. (2007) 'The Political Economy of Adjustment in Mixed Market Economies: A Study of Spain and Italy' in Hancké, et al. (eds), Beyond Varieties of Capitalism: Conflict, Contradictions, and Complementarities in the European Economy. Oxford: Oxford University Press, pp. 223-252.

Muñoz de Bustillo, R. and Antón, J-I. (2011): 'From the highest employment growth to the deepest fall: Economic crisis and labour inequalities in Spain', in Vaughan-Whitehead, D. (ed.): Work inequalities in the crisis. Evidence from Europe. Cheltenham: Edward Elgar, pp. 397-448.

Muñoz de Bustillo, R. and Antón, J-I. (2013) 'Those Were the Days, My Friend: The Public Sector and the Economic Crisis in Spain', in Vaughan-Whitehead, D. (ed.): Public Sector Shock. The Impact of Policy Retrenchment in Europe, Cheltenham: Edward Elgar, pp. 511-542.

Picot, G. and Tassinari, A. (2017) 'All of one kind? Labour market reforms under austerity in Italy and Spain', Socio-Economic Review 15(2): 461-482.

Prosser, T. (2015): 'Dualization or liberalization? Investigating precarious work in eight European countries', Work, Employment and Society 30(6): 949-965.

Rocha, F. (2014): 'Crisis and Austerity Policies in Spain: Towards an authoritarian model of industrial relations' in Rocha, F (ed.) The New EU Economic Governance and its Impact on the National Collective Bargaining Systems. Madrid: CCOO, pp. 175-204

Rubery, J., and Grimshaw, D. (2003). The Organisation of Employment: An international perspective. Basingstoke: Palgrave

Rubery, J. and Rafferty, A. (2013) 'Women and recession revisited', Work, Employment and Society 27(3): 414-432.

Schulten, T. and Müller, T. (2015): 'European economic governance and its intervention in national wage development and collective bargaining', in Lehndorff, S (ed.), Divisive integration. The triumph of failed ideas in Europe - revisited, Brussels, European Trade Union Institute. Pp. 331-363.

Simonazzi, A. (2015) 'Italy's long stagnation' in Lehndorff, S. (ed.): Divisive integration. The triumph of failed ideas in Europe - revisited, Brussels, ETUI, pp. 69-93.

Streeck, W. (2011): 'The Crises of Democratic Capitalism', New Left Review 71: 5-29.

Thelen, C. (2009): 'Institutional Change in Advanced Political Economies', British Journal of Industrial Relations 47(3): 471-498. 
Thelen, C. (2014): Varieties of Liberalization and the New Politics of Social Solidarity, Cambridge: Cambridge University Press.

Van Wanrooy, B.; Bewley, H.; Bryson, A.; Forth, J.; Freeth, S.; Stokes, L.;. and Wood, S. (2014): The 2011 Workplace Employment Relations Study First findings. London: BIS.

Visser, J. (2016): 'What happened to collective bargaining during the great recession?', IZA Journal of Labor Policy 5(9): 1-35.

Waddington J. (2000) 'United Kingdom: recovering from the neoliberal assault?' in Waddington J. and Hoffman R. (eds.) Trade unions in Europe: Facing challenges and searching for solutions. Brussels: ETUI, pp. 575-626

Warren, T. (2015): 'Work-time underemployment and financial hardship: Class inequalities and recession in the UK', Work, Employment and Society 29(2): 191-212.

\section{Biographical note}

Martí López Andreu is Lecturer in HRM and Employment Relations at the School of Business, University of Leicester. 
Table 1. Employee transitions by period (\%)

\begin{tabular}{|c|c|c|c|c|c|c|c|c|c|}
\hline & \multicolumn{3}{|c|}{ Spain } & \multicolumn{3}{|c|}{ Italy } & \multicolumn{3}{|c|}{ UK } \\
\hline & $2004-07$ & $2007-10$ & $2010-13$ & $2004-07$ & $2007-10$ & $2010-13$ & $2005-07$ & $2007-10$ & $2010-13$ \\
\hline \multicolumn{10}{|l|}{ Employees in $t-1$ by situation in $t$} \\
\hline Real pay increase in same job & 44.7 & 44.0 & 35.0 & 51.6 & 48.3 & 43.1 & 43.6 & 40.7 & 40.3 \\
\hline Nominal increase or no change in same job & 8.7 & 7.6 & 10.4 & 9.6 & 6.1 & 10.9 & 5.6 & 4.0 & 5.5 \\
\hline Pay decrease in same job & 28.2 & 29.8 & 38.2 & 23.9 & 29.8 & 32.9 & 29.0 & 35.7 & 38.4 \\
\hline Job change & 11.0 & 7.6 & 4.4 & 9.0 & 9.6 & 4.9 & 17.7 & 12.1 & 10.8 \\
\hline Employment to unemployment & 5.2 & 9.6 & 10.5 & 2.7 & 3.4 & 5.3 & 1.1 & 2.7 & 1.9 \\
\hline Employment to education/training & 0.6 & 0.7 & 0.6 & 0.5 & 0.4 & 0.5 & 1.1 & 1.8 & 1.1 \\
\hline Employment to domestic or other inactivity & 1.6 & 0.8 & 1.0 & 2.8 & 2.4 & 2.5 & 2.0 & 3.2 & 2.0 \\
\hline \multicolumn{10}{|l|}{ Employees in same job $t-1$ and $t$} \\
\hline Real pay increase & 54.8 & 54.0 & 41.8 & 60.7 & 57.4 & 49.6 & 55.8 & 50.6 & 47.9 \\
\hline Nominal pay increase or no saly change & 10.6 & 9.3 & 12.5 & 11.2 & 7.3 & 12.6 & 7.1 & 5.0 & 6.5 \\
\hline Pay decrease & 34.6 & 36.7 & 45.7 & 28.1 & 35.4 & 37.8 & 37.1 & 44.4 & 45.6 \\
\hline \multicolumn{10}{|l|}{ Employees in different job $t-1$ and $t$} \\
\hline Real pay increase & 55.3 & 52.1 & 50.2 & 61.9 & 58.4 & 50.7 & 62.7 & 51.6 & 50.5 \\
\hline Nominal increase or no change & 6.6 & 6.0 & 2.9 & 6.8 & 3.9 & 7.0 & 6.0 & 2.9 & 5.7 \\
\hline Pay decrease & 38.1 & 41.8 & 56.9 & 31.3 & 37.7 & 42.3 & 31.3 & 45.5 & 43.8 \\
\hline
\end{tabular}


Table 2. Logistical regression of the risk of transitions to unemployment and pay decreases: interaction by period.

\begin{tabular}{|c|c|c|c|c|c|c|}
\hline & \multicolumn{2}{|c|}{ Spain } & \multicolumn{2}{|c|}{ Italy } & \multicolumn{2}{|c|}{ UK } \\
\hline & Unemp. ${ }^{a}$ & Decrease $^{b}$ & Unemp. ${ }^{a}$ & Decrease $^{b}$ & Unemp. ${ }^{a}$ & Decrease $^{b}$ \\
\hline Women (ref Men) & $1.89 * * *$ & 0.92 & 1.06 & $0.93 *$ & 0.97 & 1.02 \\
\hline Period (ref 2004--07) & & & & & & \\
\hline 2007--10 & $1.93^{* * *}$ & 1.00 & 0.89 & 0.88 & 0.25 & $1.59^{*}$ \\
\hline $2010--13$ & $2.25 * * *$ & 0.85 & 0.81 & 1.21 & 0.89 & $1.38^{*}$ \\
\hline Gender*period (ref 2004--07) & & & & & & \\
\hline Women*(2007--10) & $0.54 * * *$ & 1.04 & 1.06 & 1.03 & 0.73 & 0.94 \\
\hline Women*(2010--13) & $0.48^{* * *}$ & 1.05 & $0.74 * *$ & 1.07 & 0.58 & 1.08 \\
\hline Age2 & $0.99^{* * *}$ & $1.00 * * *$ & $0.99 * * *$ & $1.00 * * *$ & $0.99^{* * *}$ & $1.00 * * *$ \\
\hline Age2*period (ref 2004--07) & & & & & & \\
\hline Age $2 *(2007--10)$ & 0.99 & 0.99 & 0.99 & $1.00 * * *$ & $1.00 * *$ & 1.00 \\
\hline Age2*(2010--13) & 1.00 & $1.00 * * *$ & $1.00 * * *$ & $1.00 * * *$ & $1.00 * *$ & 0.99 \\
\hline $\begin{array}{l}\text { Occupation t-1 (ref } \\
\text { elementary occupations) }\end{array}$ & & & & & & \\
\hline Managers & $0.46^{* *}$ & $0.71 * *$ & $0.49 * *$ & 0.93 & $0.31 * * *$ & 0.89 \\
\hline Professionals & $0.15 * * *$ & 0.88 & $0.31 * * *$ & $0.67 * * *$ & $0.08 * * *$ & $0.73 * * *$ \\
\hline Associate professionals & $0.49 * * *$ & 0.92 & $0.32 * * *$ & $0.81 * * *$ & $0.26^{* * *}$ & 0.95 \\
\hline Clerical workers & $0.36^{* * *}$ & $0.87 *$ & $0.35^{* * *}$ & 0.89 & $0.46^{* *}$ & 0.89 \\
\hline Service and sales workers & $0.72 * * *$ & 0.90 & 0.78 & 0.89 & $0.27 * * *$ & 0.89 \\
\hline Skilled Manual & 0.86 & 0.95 & 0.83 & 0.94 & $0.42 *$ & 0.91 \\
\hline Plant and machine operators & $0.74 *$ & 0.96 & $0.55 * * *$ & 0.89 & 1.06 & 1.02 \\
\hline $\begin{array}{l}\text { Occupation t-1*period (ref } \\
\text { 2004--07) }\end{array}$ & & & & & & \\
\hline Managers (2004--07) & 0.66 & 1.27 & 1.09 & 1.12 & 1.98 & 1.2 \\
\hline Managers (2007--10) & 0.45 & $1.76^{* * *}$ & 0.65 & 0.96 & 1.6 & 1.08 \\
\hline Professionals*(2007--10) & 1.02 & 0.97 & 1.72 & $1.28^{* *}$ & 3.37 & 1.24 \\
\hline Professionals (2010--13) & $1.71 * *$ & $2.58 * * *$ & 0.94 & $1.66^{* * *}$ & 2.44 & $1.53 * * *$ \\
\hline $\begin{array}{l}\text { Associate professionals } \\
(2007--10)\end{array}$ & 1.36 & 0.88 & 1.26 & $1.26^{* *}$ & $4.83 *$ & 0.88 \\
\hline $\begin{array}{l}\text { Associate professionals } \\
(2010--13)\end{array}$ & 0.95 & $1.37 * *$ & 1.04 & 1.13 & 1.02 & 1.02 \\
\hline Clerical workers (2007--10) & $1.65 * * *$ & 1.06 & 1.29 & 1.01 & 1.54 & 1.05 \\
\hline Clerical workers (2010--13) & $1.66^{* *}$ & $1.42 * * *$ & $1.59 *$ & 0.94 & 0.94 & 0.99 \\
\hline $\begin{array}{l}\text { Service and sales workers } \\
(2007--10)\end{array}$ & 1.1 & 1.16 & 0.85 & 1.06 & 2.69 & 0.87 \\
\hline $\begin{array}{l}\text { Service and sales workers } \\
(2010--13)\end{array}$ & 0.94 & 1.14 & 1.29 & 1.11 & 1.92 & 1.11 \\
\hline Skilled manual (2007--10) & $1.52 * * *$ & 1.1 & 1.12 & 1.11 & 1.01 & 1.01 \\
\hline Skilled manual (2010--13) & $1.35^{*}$ & 0.93 & 1.13 & 0.87 & 0.61 & 1.27 \\
\hline $\begin{array}{l}\text { Plant and machine operators } \\
(2007--10)\end{array}$ & 1.14 & 1.15 & 1.48 & $1.49 * * *$ & $1.03 * *$ & 1.38 \\
\hline $\begin{array}{l}\text { Plant and machine operators } \\
(2010--13)\end{array}$ & 0.99 & $0.76^{*}$ & $1.55^{*}$ & 0.95 & 0.74 & 0.86 \\
\hline Part-time t-1 & 1.16 & $1.15^{*}$ & $1.31 *$ & $1.23 * * *$ & 1.01 & $1.14^{*}$ \\
\hline $\begin{array}{l}\text { Part-time t- } 1 * \text { period (ref } \\
\text { 2004--07) }\end{array}$ & & & & & & \\
\hline
\end{tabular}




\begin{tabular}{|l|l|l|l|l|l|l|}
\hline Part-time (2007--10) & 1.07 & 0.84 & 1.21 & 1.03 & 1.52 & 0.78 \\
\hline Part-time (2010--13) & 0.99 & $0.78^{* *}$ & 1.23 & $0.71^{* * *}$ & 1.61 & $0.79^{* *}$ \\
\hline Temporary t-1 & $4.25^{* * *}$ & $0.66^{* * *}$ & $5.28^{* * *}$ & 1.09 & $7.91^{* * *}$ & 1.01 \\
\hline $\begin{array}{l}\text { Temporary t-1 } \text { period (2004-- } \\
\text { 2007) }\end{array}$ & & & & & \\
\hline Temporary t-1 (2007--10) & $1.33^{* * *}$ & $1.14^{*}$ & 1.12 & 0.87 & 0.75 & 0.93 \\
\hline Temporary t-1 (2010--13) & $1.37^{* * *}$ & 0.97 & 1.24 & $0.69^{* * *}$ & 0.65 & 1.08 \\
\hline Diference working hours & na & $0.98^{* * *}$ & na & $0.98^{* * *}$ & na & $0.97 * *$ \\
\hline $\begin{array}{l}\text { Diference woking } \\
\text { hours*period (ref 2004--07) }\end{array}$ & \multicolumn{1}{|l}{} & & & & \\
\hline $\begin{array}{l}\text { Diference working hours } \\
\text { (2007---10) }\end{array}$ & na & 1.00 & na & 1.00 & na & 0.99 \\
\hline $\begin{array}{l}\text { Diference working hours } \\
\text { (2010-13) }\end{array}$ & na & $1.02^{* * *}$ & na & 1.00 & na & 0.99 \\
\hline Constant & $0.05^{* * *}$ & $0.62^{* * *}$ & $0.08^{* * *}$ & $0.42^{* * *}$ & $0.07 * * *$ & $0.55^{* * *}$ \\
\hline N(obs) & 37331 & 29150 & 42616 & 36766 & 13506 & 12378 \\
\hline R2 & 0.1469 & 0.0323 & 0.1396 & 0.0174 & 0.07 & 0.02 \\
\hline Sig & 0.00 & 0.00 & 0.00 & 0.00 & 0.00 & 0.00 \\
\hline
\end{tabular}

$*$ Significant at $<.1 ; * *$ Significant at $<.05 ; * * *$ Significant at $<.01$.

${ }^{a}$ Ref. employee

${ }^{b}$ Ref. real pay increase 